Institute for Research on Poverty

Discussion Paper no. 1060-95

\title{
Recent Trends in U.S. Male Work and Wage Patterns: An Overview
}

\author{
Lawrence Buron \\ Abt Associates \\ Bethesda, Maryland \\ Robert Haveman \\ Department of Economics \\ University of Wisconsin-Madison \\ Owen O'Donnell \\ Department of Economics \\ University of Kent
}

March 1995

The major part of this research was undertaken while Larry Buron was a graduate student and Owen O'Donnell was a Visiting Assistant Professor at the University of Wisconsin-Madison. The support of the Jerome Levy Institute of Bard College (N.Y.) is gratefully acknowledged. This project was also supported by a grant to the Institute for Research on Poverty by the Department of Health and Human Services, Office of the Assistant Secretary for Planning and Evaluation. The Unicon Research Corporation kindly supplied the CPS data in a convenient CD-ROM form. 


\begin{abstract}
This paper brings together figures on recent trends in the labor market activity and wages of working-age men in the United States over the 1967-1992 period. The data, which come from Current Population Surveys, reveal several important developments. Year-long joblessness, the percentage of men failing to participate in the labor force, and the proportion who were unemployed rose throughout the period. Part-time employment as a percentage of all forms of employment was also higher at the end of the period than at the beginning, and the average hours worked by full-time workers increased slightly. Finally, median and mean wages fell. None of the trends was due to changes in the racial, educational, and age composition of the male work force; in fact, if the racial/educational/age composition had remained the same over the period, labor market activity would have declined even further.
\end{abstract}




\section{Recent Trends in U.S. Male Work and Wage Patterns: An Overview}

\section{INTRODUCTION}

In this paper, we survey the primary trends in the U.S. labor market from the late 1960s through the early 1990s. We focus on males who are between the ages of 18 and 64 - the working-age male population.

This has been a turbulent time for American male workers, and economists have written much about it. Average earnings have stagnated, reflecting low growth in labor productivity; earnings inequality has risen as the wage rates and earnings of highly skilled workers have grown substantially, while the returns from work to those with few or rudimentary skills have dropped; the ratio of part-time to full-time workers has grown; and the incidence of nonwork-joblessness—has increased, especially for workers with little education. Here, we document how these and other patterns have evolved over time, in an effort to provide a richer understanding of labor market changes and their implications for policy.

In our discussion, we briefly review the findings of the research literature on recent labor market developments, and supplement these findings with an extensive series of graphs generated from the 1968-1993 March Current Population Surveys (CPS). In these figures, we plot a number of important indicators of the labor market experience of civilian, nonstudent males aged 18-64 over the 1967-1992 period (see Appendix A for a description of our data and sample). These trends are presented for the entire working-age male population, for racial groups within this population, and for race-education and race-age specific groups. The indicators of labor market activity examined are (see Appendix B for precise definitions):

i) the ratio of nonemployed males in our sample to the population of all males in our sample (the "jobless" rate)

ii) the labor force nonparticipation rate

iii) the rate of unemployment 
iv) part-time/total employment

v) hours per week of full-time workers

vi) median and mean real wages.

The March CPS asks about labor market activity during the previous year. We use this information in the construction of most of the above indicators. Consequently, our measures show, on average, the labor market experience of individuals over a whole year and thus differ from the more conventional indicators, such as those generated from monthly data by the Bureau of Labor Statistics (BLS), which show average activity at a given point in time in the year. In particular, we examine trends in the proportion of males who do not work, or do not participate in the labor market, at all in a year. These rates of year-long nonwork and nonparticipation will obviously be lower than the proportion of the population not working, or not participating, in a given week of the year, the latter indicators being equal to one minus the conventional employment and participation ratios.

In order to interpret the time trends displayed below, a rough idea of the pattern of aggregate economic activity over the 1967-1992 period is required. The following lists the business-cycle peaks and troughs over the period (U.S. Department of Commerce, 1993):

\begin{tabular}{ll}
$\underline{\text { Troughs }}$ & $\underline{\text { Peaks }}$ \\
\hline 1970, Q4 & 1969, Q4 \\
1975, Q1 & 1973, Q4 \\
1980, Q3 & 1980, Q1 \\
1982, Q4 & 1981, Q3 \\
1991, Q1 & 1990, Q3
\end{tabular}

While the first year of the time series we display records labor market activity in a year during the middle of a sustained period of growth and close to a business-cycle peak, the final year, 1992, records activity for the first full year of a recovery. Knowledge of peaks and troughs by itself, however, does not convey information regarding the actual level of economic activity in any particular year. The following series of GDP growth rates also facilitates interpretation of labor market trends: 


$\begin{array}{rrrr}1968 & 4.2 & 1981 & 1.8 \\ 1969 & 2.7 & 1982 & -2.2 \\ 1970 & .0 & 1983 & 3.9 \\ 1971 & 2.9 & 1984 & 6.2 \\ 1972 & 5.1 & 1985 & 3.2 \\ 1973 & 5.2 & 1986 & 2.9 \\ 1974 & -.6 & 1987 & 3.1 \\ 1975 & -.8 & 1988 & 3.9 \\ 1976 & 4.9 & 1989 & 2.5 \\ 1977 & 4.5 & 1990 & .8 \\ 1978 & 4.8 & 1991 & -1.2 \\ 1979 & 2.5 & 1992 & 2.6\end{array}$

(Council of Economic Advisors, 1994, Table B-1).

The first year we examine (1967) was a year of moderate growth. GDP increased by 2.6 percent from 1966 to 1967; that followed an increase of 5.9 percent the previous year (not shown) and was followed by an increase of 4.2 percent in the following year. In the last year of our series, 1992, GDP increased by 2.6 percent following the economic slump of 1991. In comparing levels of labor market activity from the first to the last year of our series, readers should keep these patterns in mind.

Controlling for the business cycle, differences over time in labor market activity reflect structural changes - in the demographic composition of the group of working-age males, in labor demands (such as those due to import penetration or technological developments), in incentives from public transfer policies, in labor market policy, and in worker tastes for leisure. While the allocation of responsibility for changes in activity among these sources can be made with only limited accuracy, we are able to shed some light on the contribution of one of the sources, that of demographic change. In addition to showing the actual trends in our labor market indicators, we also give trends standardized for changes in the race, age, and education composition of the male working-age population. In effect, this standardized series shows how activity would have changed over time if race/age/education-specific rates had followed the trends we actually observe but the demographic composition of the population remained as it was in 1967 (1975 for some series). 


\section{THE NONEMPLOYMENT-POPULATION (JOBLESS) RATIO}

The aggregate (male plus female) U.S. employment-population ratio ${ }^{1}$ has risen steadily over the entire post-World War II period (Council of Economic Advisors, 1994, Table B-33). However, this aggregate picture is the product of two rather disparate patterns-rapidly increasing female employment rates, and a declining rate of male employment (ibid., Table B-37). The former trend has outweighed the latter.

The Bureau of Labor Statistics (BLS) uses data collected monthly to calculate the employmentpopulation ratio and to show the percentage of the population in employment in a typical week of the year. One minus this would obviously give the percentage not working, on average, at a given point in time. Here, we define the jobless rate differently, including in the numerator only males who report not working at all during the previous year. Obviously, this year-long jobless rate will be lower than one minus the conventional employment-population ratio.

Figure 1 presents the trend in the jobless rate, so defined, over the 1967-1992 period for civilian, nonstudent males of working age, distinguished by race. ${ }^{2}$ The trend standardized for changes in the demographic composition of the population is also depicted. The actual rate follows a clear upward trend over the period. The periods leading up to and during the major recessions of 1974-1975 and the early 1980s show steep increases in the year-long jobless rate. The rate experienced a further abrupt increase in the recession of the early 1990s. ${ }^{3}$

The pattern during the recoveries after both of the earlier recessionary periods shows a failure of the male employment rate to return to its prerecession levels. One interpretation of this pattern is that there is a "ratchet effect" operating on the rate of joblessness. That is, men who lose their jobs 
Figure 1 here 
during a recession find it difficult to regain employment when the economy recovers, and so, over time, each recession brings a cumulative increase in long-term joblessness. This interpretation requires a strong "state dependence" effect on employment probabilities; that is, the longer an individual is not working, the less likely he or she will reenter employment. Such an effect may arise either because nonwork reduces an individual's tastes for work or potential employers take nonwork as a signal of low productivity (see, e.g., Clark and Summers, 1982). However, a ratchet effect does not explain the increase in the rate of joblessness from 1967 to 1973, a period in which there was only a slight recession. The pattern seems more consistent with a long-run growth in joblessness, the rate of which increases during recessionary periods but fails to decline in recoveries, ensuring a return to the long-run growth path.

As noted in the first paragraph of this section, the upward trend in male joblessness after 1967, shown in Figure 1, is not a new phenomenon. In general, male employment has followed this path for the past forty-five years. The conventionally defined male employment-population ratio fell from .82 in 1950 to .72 in 1990 (Council of Economic Advisors, 1994, Table B-37). By 1960, 31 percent of the 1950-1990 decline had occurred, 57 percent of the fall had taken place by 1970, and 99 percent by 1980 (ibid., Table B-37). Comparing the average male employment rate for one decade with that of the previous one reveals declines in the rate of employment of 4.9 percent, 4.7 percent, and 4.2 percent in the 1960s, 1970s, and 1980s, respectively (ibid.). These figures confirm that the recent downward trend in the conventionally defined male employment rate is a continuation of a long-run pattern; the best that can be said is that the rate of decline appears to have slowed during the 1980s. Unfortunately, data are not available to compare the increase in the fraction of males without a job for a full year over the 1967-1992 period with that for the first half of the post-WWII period. However, examination of the rate of increase in this fraction over our period of study, together with its absolute level at the beginning of the period, indicates the increase has been large in comparison with previous experience. The rate of 
year-long male joblessness increased from 3.8 percent in 1967 to 10.6 percent in 1992-a rise of 177 percent. Even if this rate of increase were matched in the previous twenty-six years, 75 percent of the increase from 1943 to 1992 would still have taken place in the 1967-1992 period. This suggests that both the increase in, and the magnitude of, long-term male joblessness experienced in recent years are large in comparison with earlier periods.

In addition to showing the high prevalence of nonwork that now exists among prime-age males, Figure 1 reveals the large racial disparity. Year-long jobless rates were 9 percent and 16 percent for whites and nonwhites, respectively, in 1992, increases from about 3.5 percent and 6.5 percent in 1967. The absolute difference between the two racial groups has therefore increased over time (from 3 to 7 percentage points), but the relative difference has remained roughly constant (see Table 1). The figure also reveals that the nonemployment of nonwhites is more sensitive to the cycle than that of whites; the racial disparity widens during recessionary periods and narrows during upturns in the cycle.

In Figure 2, we present year-long jobless rates over the period for both nonwhites and whites, broken down by age and education levels. The patterns are similar for both racial groups. While jobless rates have increased within all age groups, by far the most dramatic increase has been experienced by males aged 55-64. By the end of the period, 26 percent and 37 percent of white and nonwhite males, respectively, in this age group were without a job for at least a year (up from about 10.5 and 15.5 percent, respectively, in 1967). In Table 2 we summarize the increasing disparity by age in this indicator. The 1992 difference between the age groups with the highest (55-64 year olds in this case) and lowest (25-39 year olds in this case) rates of joblessness is expressed as a ratio of the 1967 difference between the high and low rates. This reveals that the age disparity in joblessness at the end of the period was over twice that at the beginning. Of the three nonelderly age groups, 
TABLE 1

Change in Absolute and Relative Differences between Whites and Nonwhites: 1967(1975)-1992

\begin{tabular}{lcc}
\hline & Absolute Difference & Relative Difference \\
\hline Joblessness & 2.31 & 1.05 \\
Nonparticipation & 2.25 & 1.04 \\
Unemployment & 1.24 & 0.85 \\
Part-Time Rate & 0.65 & 0.60 \\
Mean Hours (Full-Time Workers) & 1.02 & 1.00 \\
Median Wage & 1.17 & 1.09 \\
\hline
\end{tabular}

Note: The figures in the columns are ratios of the 1992 difference between whites and nonwhites to the 1967 difference (or 1975 difference, in the case of hours and wages) between whites and nonwhites. 
Figure 2 here 
TABLE 2

\section{Change in the Absolute Difference between High and Low Rates across Age and Education Groups: 1967(1975)-1992}

\begin{tabular}{lcc}
\hline & Age $^{\mathrm{a}}$ & Education $^{\mathrm{b}}$ \\
\hline & & \\
Joblessness & 2.24 & 4.34 \\
$\quad$ Whites & 2.05 & \\
$\quad$ Nonwhites & & 4.34 \\
& & 2.12 \\
Nonparticipation & 2.31 & 2.43 \\
$\quad$ Whites & 2.12 & \\
$\quad$ Nonwhites & & 2.17 \\
& & 1.86 \\
Unemployment & 2.06 & \\
$\quad$ Whites & 2.29 & 3.30 \\
$\quad$ Nonwhites & & 2.36 \\
& & \\
Part-Time Rate & 1.82 & 1.65 \\
$\quad$ Whites & 1.77 & 2.21 \\
$\quad$ Nonwhites & & \\
Mean Hours (Full-Time Workers) & & 1.61 \\
$\quad$ Whites & 1.36 & 1.58 \\
$\quad$ Nonwhites & 1.16 & \\
& & \\
Median Wage & 1.28 & \\
Whites & 1.41 & \\
Nonwhites & & \\
\hline
\end{tabular}

Note: The figures in the columns are ratios of the 1992 difference between whites and nonwhites to the 1967 difference (or 1975 difference, in the case of hours and wages) between whites and nonwhites.

${ }^{a}$ For joblessness and nonparticipation, high and low rates are contributed by the 55-64 years group and the 25-39 years group, respectively. The 18-24 years group contributes the high rate of unemployment and part-time work and the low rate for mean hours and the median wage. For the latter two indicators, the 40-54 years group has the high rate. The low rate for unemployment is held by the 55-64 years group. For part-time work, the 25-39 years group has the low rate in 1967 and the 40-54 years group has it in 1992.

${ }^{\mathrm{b}}$ The comparison is between the most- and least-educated for all of the indicators. 
jobless rates have been increasing most rapidly within the youngest (18-24 years) group. The respective year-long jobless rates among white and nonwhite young males stood at 6 percent and 17 percent in 1992. Given that students are excluded from this calculation, the 17 percent rate for nonwhites — up from a rate of 6 percent in 1967—is especially noteworthy.

Among the education groups, the rise in year-long jobless rates is greatest for those with a high school diploma or less; in particular, both whites and nonwhites who dropped out of high school experienced enormous reductions in employment rates over the period. By 1992, over 24 percent of white dropouts and 25 percent of nonwhite dropouts did not hold a job at all during the year. The jobless rates for these two racial groups of high school dropouts were 6 percent and 8.5 percent, respectively, in 1967. While joblessness has grown rapidly for dropouts of both racial groups over the period, the racial disparity within this education group has narrowed. The rather rapid increase in joblessness for both whites and nonwhites who had only a high school diploma is also noteworthy - from 2 to 9.5 percent for whites and from 3 to 17 percent for nonwhites, over the period. The figures in Table 2 summarize the increasing disparity in joblessness, and in all of the other indicators we examine, between education categories. For whites and nonwhites respectively, the 1992 difference between the jobless rates of dropouts and college graduates was 4.3 times and 3.3 times greater than the 1967 difference between these two education groups.

Figures 1 and 2 illustrate the large differences in jobless rates that exist between race, age, and education groups. Given these differences, shifts over time in the distribution of the population across demographic groups will directly change the mean rate of joblessness. Since 1967, nonwhites have increased as a fraction of the male population, while the lowest education groups and the youngest and oldest age groups have all declined in relative size (Buron, Haveman, and O'Donnell, 1994). Whereas the change in the racial composition of the population will have reduced the mean rate of labor market activity, the changes in the age and education distributions will have had the opposite effect. In order to 
determine the net effect of demographic change and to gauge its contribution to the trends observed, we have undertaken direct standardizations of the year-long jobless rate and the other indicators examined. This involves weighting the activity rate of each race/age/education group in a given year by the number of individuals in this demographic cell in $1967 .{ }^{4}$ Examination of trends in the standardized rates then reveals what mean activity would have been in each year if the cell-specific activity was as observed in that year but the demographic composition had remained as it was in $1967 .{ }^{5}$

In Figure 1, the standardized year-long jobless rate lies above the actual rate throughout the period. This implies that the net effect of demographic change on joblessness has been negative; if there had been no change in the race/age/education structure of the male 18-64-year-old population since 1967, but cell-specific rates had changed as they did, the increase in joblessness would have been even greater than has been experienced. In fact, by 1992 the standardized rate had almost reached the rate of joblessness experienced by nonwhites. The trend in the standardized rate does not show what would have happened to joblessness if there had been no demographic change, since there is no allowance for the possibility that shifts in the distribution of the population across cells would affect activity within those cells. However, the standardization exercise does make clear that the dramatic increase in joblessness we observe is not merely an artifact of the population having a different demographic structure. Indeed, accounting for demographic change gives an even worse picture of labor market performance. ${ }^{6}$

In Table 3 we split the change in the jobless rate and other indicators between 1967 and 1992 into that arising from demographic change and that due to changes in cell-specific rates, and then further decompose the demographic effect into the separate contributions of shifts in the population across race, age, and education groups. These latter decompositions are carried out using the methodology of Das Gupta (1978). ${ }^{7}$ While the year-long jobless rate increased by 6.75 percentage 
TABLE 3

Decomposition of Change in Labor Market Inactivity Indicators and Wage Rates, 1967(1975)-1992

\begin{tabular}{|c|c|c|c|c|c|c|}
\hline & $\begin{array}{l}\text { Jobless } \\
\text { Rate }\end{array}$ & $\begin{array}{l}\text { Nonparticipation } \\
\text { Rate }\end{array}$ & $\begin{array}{l}\text { Unemployment } \\
\text { Rate }\end{array}$ & $\begin{array}{l}\text { Part/Total } \\
\text { Employment }\end{array}$ & $\begin{array}{l}\text { Mean Hours/Week } \\
\text { of Full-Time Hours }\end{array}$ & $\begin{array}{c}\text { Mean Wage of Wage } \\
\text { Salary Workers }\end{array}$ \\
\hline 1967(1975) & 3.82 & 3.59 & 8.77 & 3.51 & 44.36 & 14.99 \\
\hline 199210.57 & 8.99 & 16.70 & 7.76 & 44.65 & 14.60 & \\
\hline $\begin{array}{l}\text { Actual difference: } \\
\quad 1992-1967(1975)\end{array}$ & 6.75 & 5.40 & 7.93 & 4.25 & 0.29 & -0.39 \\
\hline $\begin{array}{l}\text { Difference not due } \\
\text { to demographics }\end{array}$ & 9.61 & 8.14 & 10.01 & 5.31 & 0.13 & -1.56 \\
\hline $\begin{array}{l}\text { Difference due to } \\
\text { demographics } \\
\text { Total }\end{array}$ & -2.86 & -2.75 & -2.09 & -1.06 & 0.16 & 1.17 \\
\hline $\begin{array}{l}\text {-Race } \\
\text {-Age } \\
\text {-Education }\end{array}$ & $\begin{array}{r}0.60 \\
-0.48 \\
-2.97\end{array}$ & $\begin{array}{r}0.45 \\
-0.49 \\
-2.70\end{array}$ & $\begin{array}{r}0.79 \\
0.46 \\
-3.34\end{array}$ & $\begin{array}{r}0.30 \\
-0.10 \\
-1.26\end{array}$ & $\begin{array}{r}-0.20 \\
0.11 \\
0.25\end{array}$ & $\begin{array}{r}-0.28 \\
0.30 \\
1.15\end{array}$ \\
\hline
\end{tabular}

Source: Own calculations, 1968-1993 CPS.

Note: In the case of hours and wages, the change is that which occurred between 1975 and 1992. 
points between 1967 and 1992, the difference arising from changes in cell-specific rates, holding the relative size of the cells constant, would have been 9.61. The difference between these two figures is the offsetting demographic effect (-2.86 percentage points). The final three rows of the table show the separate contributions of race, age, and education to this demographic effect. As expected, while changes in the age and education distributions have reduced mean joblessness, the opposite is true for the change in the race composition. The dominant demographic effect is that of education. If everything else were constant, the decline in the fraction of males who are high school dropouts and the increase in college graduates between 1967 and 1992 would have reduced the rate of joblessness by 2.97 percentage points.

The standardization results confirm that the increase in male joblessness is not attributable to demographic change, leaving the question of what is responsible for this increase. Detailed assessments of competing explanations have been carried out by Juhn, Murphy, and Topel (1991) and Juhn (1992). These two studies use similar techniques and concentrate on nonstudent, civilian males with 1-40 (or 1-30) years of potential labor market experience. ${ }^{8}$ The main findings are that changes in wage rates cannot account for the fall in employment from the late 1960s to the early 1970s. This suggests shifts in labor supply may be responsible for the decline over this period. However, from the early 1970 s to 1987 , the evidence points to downward shifts of labor demand along stable supply curves accounting for most of the decline in the employment of whites, and for about one-half of the decline for blacks. The larger relative decline in employment among blacks over the latter period is attributed to an upward shift in the labor supply function of this population. ${ }^{9}$

These studies provide some support for the proposition that the increase in joblessness among males with low educations, and/or few job skills since the early 1970s is primarily due to a decline in the demand for such labor. The main support for this hypothesis is that real wages have moved in the same direction as employment for this group. ${ }^{10}$ Possible explanations for the shift in labor demand 
away from low-skilled male labor include greater competition in international trade, technological innovation, and/or competition from an expanded female and immigrant labor force (Juhn, 1992). Although it is difficult to tell which of these factors has had the greatest effect, the weight of evidence has begun to point toward technological change holding primary responsibility (Berman and Machin, 1994; Bound and Johnson, 1992).

If real wages were perfectly flexible downward, the shift in labor demand would have been accompanied by a movement along the supply curve, and the increase in joblessness would have taken the form of increased nonparticipation. In this case, the increased joblessness would be entirely voluntary—given the wages offered, fewer individuals chose to work. Alternatively, if there were some resistance to real wage falls, the increased joblessness would consist of both greater unemployment and nonparticipation. Juhn, Murphy, and Topel (1991) attribute about one-half of the secular increase in joblessness among prime-age males between the late 1960s and the late 1980s to an increase in labor force nonparticipation; the remaining one-half is attributed to increased unemployment. Since their sample excludes older males (it contains males with 1-30 years of labor market experience, which corresponds to an approximate age range of $18-48$ for high school graduates), Juhn, Murphy, and Topel's findings understate the relative importance of the decline in labor force participation for all males. This said, additional support for the proposition that a major component of the increased joblessness is involuntary is provided by evidence showing that an increasing proportion of inactive males report a lack of employment opportunities as their reason for inactivity (Juhn et al., 1991; Buron et al., 1994). In the next two sections we examine the trends in nonparticipation and unemployment over the 1967-1992 period. 


\section{NONPARTICIPATION IN THE LABOR FORCE}

In Figures 3 and 4, we present the rate of year-long nonparticipation for all working-age males over the 1967-1992 period. We count any male who was not in the labor force at all in the year-who neither worked nor looked for work for the entire year-as a labor force nonparticipant. Figure 3 shows the overall pattern of nonparticipation rates over the 1967-1992 period, by race and standardized; Figure 4 presents the breakdown into age and education groups for the two races.

As with the male jobless rate, the overall labor force nonparticipation rate has increased dramatically over the post-1967 period for both racial groups. For both whites and nonwhites, yearlong nonparticipation more than doubled between 1967 and 1992, from about 3.3 percent to 7.7 percent for whites and 5.8 percent to 13.2 percent among nonwhites. As the figures in Table 1 make clear, while the absolute difference between the nonparticipation of nonwhites and whites has increased, the relative difference has remained roughly constant.

The growth in nonparticipation has been steadier than the growth in the jobless rate. Relative to the long-run growth path, the increases during recessionary periods are less steep than is the case with joblessness and, in the aggregate and for whites, there is little evidence of negative growth in postrecessionary periods. These differences from the time series for joblessness are to be expected, given the latter is directly affected by unemployment.

The trend in the standardized rate again shows that the growth in inactivity would have been even greater if the demographic composition of the population had remained constant (and if cellspecific nonparticipation changed as it has done). Further, while the growth in actual nonparticipation was steepest between 1967 and 1975, with slower growth thereafter and a levelling off from the mid- to late 1980s, the standardized rate has maintained about the same steep growth path throughout. The flattening of the growth in nonparticipation from the mid-1970s appears to be, at least partly, attributable to demographic change. Examination of the second column of Table 3 reveals that an 
Figure 3 here 
Figure 4 here 
increasingly educated male population has been the dominant demographic effect reducing nonparticipation.

The percentage of males not participating in the labor force at any given point in the year has increased steadily over the entire post-World War II period. The conventional (BLS) nonparticipation rate increased over 10 percentage points between 1950 and 1990 (Council of Economic Advisors, 1994, Table B-37). ${ }^{11}$ Sixty-five percent of this increase had occurred by 1970. In contrast, comparison of our year-long nonparticipation rate in 1992 (9 percent) with that in 1967 (3.6 percent) indicates that the vast majority of any post-WWII increase in the fraction of males detached from the labor market for a year or more has occurred in the past quarter century.

The age and education patterns of the increase in nonparticipation are seen in Figure 4. For both nonwhites and whites, increases are recorded for all age groups. Males aged 55-64 started the period with the greatest rates of nonparticipation and experienced by far the steepest increases. For white males over the age of 54, the nonparticipation rate rose from 10 percent to nearly 25 percent over the 1967-1992 period. The increase for nonwhites in this age group was from 14 percent to a very high 34 percent. By 1992, only two-thirds of older nonwhite males of working age were labor force participants for even part of the year. Table 2 shows the increasing disparity between age groups in labor force participation.

The increase in nonparticipation for nonwhite youths is also noteworthy. In 1967, about 5.4 percent of nonwhite males aged 18-24 neither worked nor sought work over the course of the year; by 1992, this had increased to 12.3 percent. The latter figure is triple that for whites in the same age group, who had experienced an increase from about 1 percent to 4 percent.

Disaggregation by years in school reveals the greatest increases in nonparticipation among men with the lowest educations. For whites, those without a high school diploma saw their labor force nonparticipation rate rise radically, from 5.8 percent to 21.7 percent. Indeed, by the end of the period, 
the nonparticipation rate for white dropouts exceeded that for nonwhites. In contrast, the large increase in nonparticipation for nonwhites with twelve years of schooling-from 2.6 percent to nearly 13.6 percent—has resulted in a 1992 rate for this group that is nearly double that for whites.

The dramatic increases in nonparticipation among older males has been the subject of a substantial literature. ${ }^{12}$ Incentives for early retirement in the Social Security program, which permits the receipt of retirement benefits at age 62 , are suspected to be a main cause of this increase, if not the main cause. However, although estimates show a negative impact of Social Security on the participation of older males, the magnitude of the estimated effect is small in comparison with the large fall in the participation of this group (Hurd, 1990).

The contribution of changes in the generosity and accessibility of the Social Security Disability Insurance (DI) program to the labor market withdrawal of older workers has also been extensively studied. While all researchers report that these changes account for some of the increase in nonparticipation, the range of estimates is wide. Parsons (1980) found a strong impact of the replacement ratio on the participation of males aged 55-64. Projections from his model gave a good fit to the trends in the participation of this group over the 1945-1975 period and were used to claim that the growth in DI could explain most of the decline in participation. Haveman and Wolfe (1984), using a different data set, model specification, and variable definitions, found a much smaller effect. Of the 12-percentage-point fall in the participation rate of 55-64-year-old males between 1968-1978, they attributed, at most, 2 percentage points (one-sixth) to the expansion of DI. Bound (1989), using observations of the employment experience of rejected DI applicants rather than econometric estimates, attributed, at most, 25 percent of the 1955-1980 decline in the participation of 55-64-year-old males to DI.

The research on Social Security retirement and DI suggests both programs have contributed—it is not clear how much - to the decline in the labor force participation of older males over the 
post-World War II period. This evidence of disincentive effects is consistent with the conclusions of Juhn, Murphy, and Topel (1991) and Juhn (1992) on the importance of labor demand shifts-relative to labor supply shifts_-in explaining male employment trends, once sample and temporal differences are taken into account. The latter studies exclude the older age group studied in the Social Security retirement and DI literature, and their conclusion that erosion in labor demand has accounted for the bulk of the troubling increases in joblessness refers to the younger age groups and especially to those with little schooling. Further, Juhn et al. and Juhn do find evidence of supply shifts from the late 1960s to the early 1970 s, the period during which the DI program may have exerted its strongest disincentive effects.

\section{UNEMPLOYMENT}

Securing an accurate measure of unemployment is difficult given the ambiguity of the "looking for work" condition that determines whether or not an individual will be defined as unemployed. This, as well as the discouraged worker phenomenon, ${ }^{13}$ clouds the distinction between unemployment and nonparticipation, and provides an argument for focusing on employment (or not working) as a superior indicator of labor market activity (Clark and Summers, 1979; Juhn, 1992). This notwithstanding, the unemployment rate tells us the proportion of individuals who have experienced nonwork during some period of time and who have been looking for work during this jobless period.

A number of studies have identified a secular increase in the unemployment rate dating from around 1970 (Clark and Summers, 1979; Summers, 1986; Murphy and Topel, 1987; Juhn, Murphy, and Topel, 1991; Juhn, 1992). Prior to 1970, the aggregate and the male unemployment rates moved up and down with the business cycle, returning to a fairly constant "full employment" level during periods of prosperity. Since then, however, the recessionary peaks in unemployment have been higher than 
previously experienced, and during recovery periods the rate has failed to return to its pre-1970 level (Council of Economic Advisors, 1994, Table B-34; Blank, 1994, Figure 1).

We define the annual unemployment rate as the proportion of people in the labor force who were unemployed during at least one week in the year. ${ }^{14}$ These rates will be much higher than the usually defined unemployment rate—the percentage of the labor force unemployed during a survey week. Even if a person worked most of the year, they will be counted as unemployed in our definition if they were unemployed during any week in the year. Figure 5 shows the fraction of participating males experiencing unemployment at some time in the year. The rate follows the business cycle, but the structural increase during the 1970 s is apparent. In the recessions of 1971, 1975, and 1982, the rate reached successively higher peaks $(14,18$, and 22 percent). The same pattern exists in comparing consecutive low points in the 1970s. In the mid- to late 1980s there was a large fall in the annual rate of unemployment from its high of 1982, but by the end of the decade the rate was still well above its level at the beginning of the period. ${ }^{15}$

The standardized rate stays close to the actual rate of unemployment throughout the period, indicating that, in contrast to the trends in joblessness and nonparticipation, demographic change has had relatively little impact on this measure. This is consistent with results from similar exercises carried out by Summers (1986) and Juhn et al. (1991).

Nonwhite prime-age males have generally experienced an annual unemployment rate that is about two-thirds above that for white males. In Figure 6, we show the time pattern of unemployment rates for race-age and race-schooling subgroups. Comparison with Figures 2 and 4 reveals that while joblessness and nonparticipation rates are highest for older males, the age gradient in unemployment is in the opposite direction, with males aged 18-24 experiencing by far the highest levels. For both whites and nonwhites, disaggregated time trends in unemployment are all similar to the pattern for the aggregate shown in Figure 5: a stepping up of the rate during the 1970s, and a large reduction in the 
Figure 5 here 
Figure 6 here 
1980s from the 1982 peak that was not sufficient to return to the lower levels of the late 1960s. The graphs also show a fanning out of the age- and education-specific rates, the increase in unemployment being greatest among young and poorly educated males who experienced the highest rates to start with (see Table 2). For whites without a high school diploma, the unemployment rate increased by 15.7 percentage points from 1967 to 1992, which, in both absolute and relative terms, exceeds the increase (13.6 percentage points) experienced by nonwhites in this education category.

Our graphs confirm a secular increase in unemployment from the late 1960s to the early 1980s. Since then, although there have been no further step-ups in the unemployment rate, even the sustained boom of the 1980s could not reduce unemployment to its pre-1970 levels. Efforts to explain this secular increase in unemployment have not been notably successful. For the increase to be consistent with a rise in the natural rate of unemployment, increased rates of mobility of individuals across occupations and industries—indicating increased mismatch between workers and jobs—-should be observed. However, the data do not support this hypothesis (Murphy and Topel, 1987). Search theories, which suggest that those out of work are engaging in more thorough job search before reemployment, have little relevance, given that the majority of unemployment is accounted for by long spells stretching well beyond any credible search period (Clark and Summers, 1979). Classical and neo-Keynesian theories are also of limited importance since the phenomenon to be explained is a secular increase in the unemployment rate, rather than temporary deviations that may be attributed to wage or price inflexibilities (Juhn, Murphy, and Topel, 1991).

Moreover, the unemployment rate has increased secularly, independent of aggregate economic activity, suggesting that the phenomenon is not simply a problem of aggregate demand. The predominance of job losers rather than quitters among the unemployed casts doubt on the importance of intertemporal substitution theories-the notion that workers concentrate their work time in periods when the return is particularly high (Summers, 1986). The disincentive effect of unemployment 
insurance is also not a strong candidate to explain the trend, given the unemployment rate has fallen among the insured population (Summers, op. cit.).

As noted in section II, Juhn et al. (1991) and Juhn (1992) place the primary responsibility for the decline in male employment since the early 1970s on a downward shift in relative demand for lowskilled labor. The same argument has some force in explaining the secular increase in unemployment. Summers (1986) argues there is segmentation in the labor market, with both high-wage and low-wage jobs persisting for any given skill level. Trade unions and other phenomena within the realm of insideroutsider theory—-such as on-the-job training costs—-preserve the segmentation. Summers (op. cit.) contends that structural shifts have reduced the demand for labor of a given skill level in the high-wage sector. The workers who are displaced because of this shift take longer to find another job, in the hope of returning to employment in the high-wage sector. These two explanations are consistent, providing it is lower-skill labor that has experienced the decline in opportunities in the high-wage sector.

\section{PART-TIME EMPLOYMENT}

Recent research has indicated that the proportion of civilian nonagricultural workers-both males and females_-in part-time jobs increased slowly, but steadily, from 12 percent in 1968 to over 15 percent in 1987 (the proportion peaked at 17 percent in 1982) (Blank, 1990). ${ }^{16}$ This increase has been attributed primarily to the rise in females as a proportion of the labor force: 24 percent of female workers were in part-time employment in 1987 (Blank, op. cit.). In addition, there has been some evidence of an increase in part-time employment among males (Blank, 1990). ${ }^{17}$

Figures 7 and 8 present our time series of part-time employment as a percentage of total male employment, and they provide some clues concerning the source of the growth in overall part-time work among prime-age males. Figure 7 shows spikes in the part-time work rate during each of the 
Figure 7 here 
recessions. However, the increase in this rate during the slump of the early 1980s dwarfs all of the other spikes. From a part-time work rate of about 4.5 percent in the late 1970 s, the rate increased to 7.5 percent during the 1981-1982 recession. Like the jobless rate (but not the unemployment rate), the rate of part-time employment remained high all through the 1980s, never dropping below 6 percent. During the most recent recession, the rate increased again, and it ended the period at an all-time high of nearly 8 percent.

Throughout the period, the nonwhite part-time employment rate exceeded that for whites. However, during the 1970s, the racial disparity closed as the rate increased among whites and remained roughly constant for nonwhites. As is the case for other indicators, the activity of nonwhites is more sensitive to the cycle than is the case for whites; the racial disparity in the part-time/total employment rate increases during recessionary periods. By 1992, 7.2 and 9.7 percent of white and nonwhite primeage male workers (excluding students), respectively, were employed part-time. ${ }^{18}$ This is up from about 3 and 7 percent, respectively, during the recovery of the 1960s. Both the absolute and relative difference between nonwhite and white part-time employment fell over the period (see Table 1).

The standardized rate remains close the actual rate until the mid-1980s; from then on, it appears that demographic change has tended to reduce the mean rate of part-time employment.

Figure 8 shows that for both nonwhites and whites, the growth in part-time work has been particularly rapid among workers aged 18-24 and those without a high school diploma. Since these are the age and education groups with the highest rates of part-time employment, as with the other indicators, age and education differentials in activity rates have increased over time (see Table 2). Over the 1967-1992 period, the prevalence of part-time work increased from more than 10 to over 20 percent for the youngest age group in both races (again, excluding students). Some increase in the 
Figure 8 here 
part-time employment rate is recorded for all of the race-age groups, save for the two older groups of nonwhites, where the rate held steady.

The most dramatic increase in part-time employment is for whites without a high school diploma; from the late 1960s to the present, this rate more than tripled, from about 4.5 percent to 14 percent. This increase far exceeds that for nonwhites without a high school diploma, among whom the rate increased from about 8 percent to about 13 percent over the period. By 1992, the part-time employment rate for whites with low educations exceeded that for poorly educated nonwhites. ${ }^{19}$ For all of the race-education groups save nonwhite college graduates, the part-time employment rate has drifted up over the past twenty-five years.

\section{HOURS WORKED BY FULL-TIME WORKERS}

Recent research using data from the 1940-1980 Decennial Censuses, supplemented by the CPS after 1980, has found little change in median weekly and annual hours of male employees aged 16-64 (Coleman and Pencavel, 1993). However, this aggregate picture masks changes that have occurred within particular groups. The mass at the upper tail of the hours distribution has fallen for the less-

educated, while it has increased for the well-educated, particularly for whites (Coleman and Pencavel, op. cit.). Mean hours worked have fallen and risen respectively for the two education groups. Large declines in mean weekly hours have been reported for both young and older male employees, particularly among blacks. The hours of middle-aged white male workers have changed little or increased slightly (Coleman and Pencavel, 1993).

These findings are inconsistent with the claim by Schor (1991) that mean hours have increased over the past twenty years for workers of many demographic groups. The explanation for the inconsistency appears to be that Schor, who analyzed 1969-1987 CPS data for her study, may have examined trends in hours worked by full-time, full-year workers only. The evidence of increases in 
part-time work cited in the previous section, together with the fact that there has been little change in average hours worked, also suggests an increase in hours worked by full-time employees.

Figures 9 and 10 provide evidence on the work hours of the shrinking group of full-time workers. ${ }^{20}$ In the aggregate, mean weekly hours mainly reflect the business cycle, being roughly equal either side of a severe dip during the early-eighties recession. The time pattern is similar for both white and nonwhite full-time workers, though average hours worked for whites is persistently about 2.5 hours per week greater than for nonwhites. In these race-specific rates, there is some evidence of a slight upward drift, the means in the late-1980s boom being higher than those in the late 1970s. Once disaggregation is made by age (Figure 10), there are a few exceptions to the aggregate trend; there is a slight decline in mean hours among the youngest age and lowest education groups. Further, for nonwhites, the upward trend in mean hours worked by full-time workers aged 40-54 is readily discernable, as it is for full-time workers with a college degree for both races. This evidence, for fulltime workers, is consistent with the patterns across demographic groups found by Coleman and Pencavel (1993) for all employees.

\section{REAL WAGES}

There has been a substantial—and well-documented—shift in the wage structure within the U.S. labor market over the past twenty-five years (Levy and Murnane, 1992; Burtless, 1990; Bound and Johnson, 1992; Murphy and Welch, 1992). Aggregate real wages have been stagnant or have shown a slight increase, but the absolute, and so relative, real wages of low-skilled workers have declined (Murphy and Welch, 1992). As a consequence, wage inequality has increased (Levy and Murnane, op. cit.). Most of the evidence suggests this increased dispersion of wage rates is responsible for increased earnings inequality (Burtless, 1990; Karoly, 1992; Moffitt, 1990). 
Figure 9 here 
Figure 10 here 
Figures 11 and 12 present evidence on the median wage rate of male wage and salary workers (in 1993 dollars) from 1975 to $1992 .{ }^{21}$ In Figure 11, the oft-mentioned "stagnation" of male wages is seen vividly. Over the period we have studied, the median wage fell from $\$ 13.67$ to less than $\$ 12.38$. The drop was greater for nonwhites than for whites; the nonwhite median wage fell from about $\$ 10.78$ to about $\$ 9.27 .^{22}$ Currently, the median wage of nonwhites is only about twice the nation's minimum wage.

Because of the rapid growth of wage rates for highly skilled male workers, the mean wage rate (shown in the lower part of the figure) does not reveal as large a drop as the median. The overall mean wage rate fell from $\$ 15.24$ to just over $\$ 14.85$. The mean increased slightly for whites, but fell by about $\$ .70$ for nonwhites. ${ }^{23}$ From the mid-1980s, the fall in the standardized mean has been much more pronounced than that of the actual value, again indicating the offsetting effect of demographic change. As with the other indicators, the demographic effect is primarily due to an increasingly educated work force (see Table 3).

Figure 12 shows the trend in median wages by age, education, and racial group. For both whites and nonwhites, the story is easy to summarize: while the median wage for older workers held firm, that for younger workers fell, with a strikingly large decrease from the lowest base for the youngest workers-from $\$ 8.80$ to $\$ 6.70$ for whites aged $18-24$ (a decrease of 23 percent) and from $\$ 7.60$ to $\$ 5.95$ for young nonwhites (a decrease of 22 percent). A similarly large drop for males aged 25-39 is also observed for both racial groups; indeed, the median wage for nonwhites aged 25-39 fell from $\$ 11.60$ to about $\$ 9$, or by 22 percent.

The pattern of wage-rate changes by education level is shown in the bottom panel of Figure 12 . While the wage rate for college graduates increased for both whites and nonwhites, it decreased for all other schooling groups, especially those with a high school diploma or less. For whites without a high school diploma, the decrease was over $\$ 3$ per hour — from about $\$ 12.20$ to $\$ 8.90$ — and 
Figure 12 here 
Figure 13 here 
outstripped that for nonwhites without a high school diploma (who experienced a decrease from $\$ 9.25$ to about $\$ 6.90)$.

Prior research has indicated that the labor market returns to education increased through the 1960s then declined over the 1970s, but has been increasing since the beginning of the 1980s (Murphy and Welch, 1992). Figure 12 verifies this pattern for the period since 1975. Trends in the college premium during the 1960s and 1970s have been attributed to shifts in the supply of differentially skilled labor, with stable demand (Murphy and Welch, 1992). Evidence suggests that shifts in labor demand are the dominant factor in explaining the change in the structure of wages by education level since the early 1980s. There appears to have been an increase in demand for highly educated/skilled labor that has not been met sufficiently by expanding supply (Blackburn, Bloom, and Freeman, 1990). Additionally, the demand for low-skilled labor has shifted downward, with potential explanations, as mentioned previously, being increasing competition in international trade and changes in production technology (Bound and Johnson, 1992; Murphy and Welch, 1992).

Howell (1993) has challenged the received wisdom that shifts in labor demand away from lowskilled workers toward high-skilled workers are responsible for the increased wage inequality witnessed in recent years. His alternative explanation is that there has been a rise in the demand for low-wage labor, of any given skill level. ${ }^{24}$ Howell suggests an increased demand for low-wage labor derives from increasingly competitive product markets (in part, from the importation of goods from low-wage countries), an abundant supply of low-skilled labor generated by inflows of females and immigrants into the labor market, and a political climate in the 1980s conducive to aggressive attacks on labor costs. Howell's main empirical challenge to the "shift-toward-high-skill-labor" explanation for the changing wage structure (also known as the "skill mismatch hypothesis") is that trends in the fraction of employment filled by low-skilled and low-wage workers are not consistent with the hypothesis. That is, if the hypothesis that there has been a decline in demand for low-skilled labor were true, and if one 
treats the wage and skill distributions as equivalent (as adherents to the skill mismatch explanation do), then one should see a fall in the share of employment accounted for by both low-skilled and low-wage labor. While the former trend is apparent, low-wage workers have increased as a proportion of total employment.

While neither perspective is likely to provide the whole truth, some weight must be given to the institutional changes in the labor market that Howell claims are most responsible for the poor experience of those at the bottom of the wage distribution-new policies in the private sector that encourage businesses to purchase goods and services from nonunionized vendors, increases in immigrant labor, and pro-business, anti-union public policies. Indeed, there is evidence that the decline in unionization of the work force may account for as much as 15-20 percent of the declining relative wages of low-skilled labor (Blackburn et al., op. cit.).

\section{SUMMARY AND CONCLUSIONS}

In this paper, we have documented a variety of important labor market trends for working-age males (age 18 to 64) over the twenty-six-year period from 1967 to 1992 with a consistent set of time series calculations from the CPS. We have studied this population in the aggregate and by race, raceage, and race-education groups. In the process, we have summarized proposed explanations for the observed changes in labor market activity. Our purpose is to bring together in one place the major developments that have been studied in piecemeal fashion in the literature, and to update these series to the present.

Several important secular trends and cyclical patterns have been observed for our population. First, the year-long jobless rate-the percentage of working-age males without work for an entire year-has been trending upward in a steady fashion. While recessions accelerate the increase, subsequent recoveries do not bring joblessness down to its prior levels. In 1967, fewer than 1 in 25 
working-age males were without employment for a year or more. By 1992, more than 1 in 10 males were jobless for at least a year. Such an increase in male joblessness is unprecedented in recent U.S. history.

A large part of the decrease in male employment is due to males exiting the labor force entirely, rather than experiencing unemployment. This is particularly true of the oldest age group (age 55 to 64), which experienced by far the largest increases in both joblessness and nonparticipation. By 1992, one-quarter of white males aged 55-64, and more than one-third of nonwhites in that age range, had not been employed or looked for work for at least a year. But the increase is also evident for younger males, with both joblessness and nonparticipation increasing particularly rapidly for nonwhite males aged 18-24. In the past twenty-six years a large gap has opened between the labor market attachment of high- and low-educated males. Both joblessness and nonparticipation for males without a high school diploma have increased dramatically over time. By the end of the period, one-quarter of high school dropouts were without employment for at least a year.

By no means all of the increase in male joblessness has been voluntary. A secular increase in the rate of male unemployment took place from the late 1960s to the early 1980s. There has been a decline in unemployment from the peak levels of the early 1980s but this has been insufficient to return to the pre-1970 levels. In contrast to the increase in nonparticipation, which has been greatest in the older groups, unemployment has risen most for younger males. The least-educated have also experienced the greatest increases in unemployment.

Part-time work as a share of total male employment has more than doubled over the past twenty-six years, reaching almost 8 percent by the end of the period. An increasing proportion of this part-time work appears to be involuntary (Blank, 1990). For both whites and nonwhites, the increase in part-time work has mainly been concentrated in the youngest age group and among high school 
dropouts. The increase in part-time work within these two age and education groups has been greater for whites than for nonwhites, perhaps reflecting the growing joblessness of the latter group.

In the aggregate, mean hours worked by the falling proportion of men in full-time employment show little trend. However, middle-aged and college-educated males in full-time employment are actually working longer hours.

In studying the wage patterns of wage and salary workers, we observed that, again, it is the least-educated and the youngest—and, in this case, nonwhites—who have experienced the worst labor market trends. Among all wage and salary workers, from 1975 to 1992 the median wage rate fell by $\$ 1.30$ per hour-from $\$ 13.67$ per hour to $\$ 12.38$ (1993 dollars), a decrease of over 9 percent. For nonwhites, the median wage fell more precipitously, from $\$ 10.78$ to $\$ 9.27$, a decrease of 14 percent. Across age groups, the median wage rate was steady for the older age groups, but fell substantially for workers aged less than 40 years. Those with a college degree fared well. They experienced an increase in their median wage, while the other education groups all experienced decreases. Specifically, the median wage fell $\$ 3.27$ (or 27 percent) for white high school dropouts, and $\$ 2.33$ (or 25 percent) for nonwhites without high school diplomas.

The increases in male inactivity and decreases in wages we have documented are not simply attributable to comparing the means of populations with different demographic structures over time. In fact, our standardized results show that changes in the race, age, and education composition of the male population over the past quarter century have increased mean labor market activity relative to what it would have been had the structure of the population remained constant and activity rates changed as they have within specific demographic groups. Of the demographic effects, the increase in the mean education level of the population has had the strongest positive effect on activity and wage rates. Sources other than changes in the demographic composition of the population have to be looked at to explain the deterioration in the male labor market we have documented. 
In addition to reduced levels of activity, there is greater inequality across males distinguished by race, age, and education. For three of the five indicators of activity-joblessness, nonparticipation, and unemployment - the white/nonwhite gap increased between 1967 and 1992 (see Table 1). However, relative differences between the two racial groups have generally remained constant and actually declined in two cases_-unemployment and part-time work (Table 1). Further, racial differences have not increased within all age and education groups. In particular, for the least-educated males, who have fared worst, the decline in the activity of whites has generally outpaced that of nonwhites. For all five of the activity indicators, plus real wages, the gaps between males with the most and least education increased over the twenty-six-year period studied (see Table 2). The disparity in activity levels across age groups also increased (see Table 2).

In explaining the declining activity of males, a distinction must be made between the experience of the older and younger groups. In the case of older males, the decline in employment has largely taken the form of falling participation; supply-side factors would appear to have an important role in explaining this trend. In particular, Social Security, in the form of pensions and Disability Insurance, is suspected of being a major determinant of increased rates of withdrawal from the labor market. However, despite considerable research effort, the magnitude of the effect of Social Security on participation remains largely unknown and in dispute. The weight of existing evidence suggests the decline in the labor market activity of younger, low-skilled male labor is primarily due to a shift in demand away from this type of labor, rather than a change in labor supply behavior. The main support for this proposition comes from the fact that, as we have documented, both the activity and real wages of young, low-skilled males have declined. Technological change and increased competition in international trade, in that order, have emerged as the most likely reasons for the shift in the structure of labor demand. Alternative explanations place more emphasis on changes in labor market institutions, 
such as the decline in trade union power. Further, increased supply from female and foreign-born labor may be crowding out male labor.

In addition to demanding explanation, the declining labor market activity of U.S. males requires consideration of the consequences of the trend. More than 1 in 10 working-age males being without employment for at least a year represents a substantial underutilization of labor resources. To the extent that this is the consequence of the opportunity to substitute leisure for work in a wealthy society, it is not necessarily indicative of inefficiency. However, a substantial part of the inactivity appears to be involuntary. In addition, increased nonparticipation is at least partly attributable to distortions to the work-leisure choice generated by the Social Security system. In this context, a joblessness rate in excess of 1 in 10 represents inefficiency in the deployment of the available labor resources.

If an increasing number of males do not obtain an income through work, then how do they finance their consumption? Older inactive males may rely mainly on Social Security, private pensions paid on early retirement, or savings. Under the current system of financing Social Security, payments to an increasing fraction of older men who withdraw from the labor force before the age of 65 must be funded through increasing intergenerational transfers. Such transfers reduce further the labor market opportunities of younger cohorts. Young inactive males have little entitlement to transfer payments and must rely on their families, or turn to crime, to provide resources. It has been noted elsewhere that the fraction of males in prison now exceeds the fraction without work (Nasar, 1994). Both the economic and social consequences of the declining labor market activity of U.S. males demand that increased attention be given to this issue. 


\section{Appendix A-Data and Sample}

Our graphs of labor market activity are based on samples of civilian, nonstudent males aged 18-64 in the 1968 to 1993 March Current Population Surveys (CPS); the males were neither in the military nor in school in the previous year. The CPS is administered by the Bureau of the Census to over 50,000 households and is the primary source of our nation's unemployment and income figures.

We exclude people known to be in the military in the previous year because, prior to the 1984 survey, it appears that their military earnings are included in their annual earnings, but the time spent in the military is not included in their annual weeks worked. Up to the 1983 survey, people in the military last year are identified if they respond that the reason they did not work or the reason they worked only part-year was because they were in the armed forces. From the 1984 survey onward, they were identified as being in the military last year if they list their occupation at their longest job last year as the armed forces.

Students are identified through current economic status. Additionally, "school/housework" can be given as a reason for working only part-time. Since the vast majority of males are likely to give this reason because they are in school, we also use this response to identify students. Those who were students in the previous year are identified through giving "school" as the reason for not working at all last year, or working for only part of the year.

Our use of CPS data was greatly facilitated by the use of Unicon Research Corporation's uniform CPS files. Unicon has organized the March CPS data from 1964 to the present on a single CD disk. With the use of their utilities, we were able to extract variables from each year with the same extract program. In cases where the question or possible responses have changed over time, their utilities allow you to either extract the original variable or a uniform variable where the responses have been recoded to be consistent over the years. We would like to thank Finis Welch for making these data available to us and Eanswythe Grabowski for answering questions about the use of their CD. 


\section{Appendix B-Definitions of Indicators of Labor Market Activity}

i) Jobless ratio-

Fraction of civilian, nonstudent males aged 18-64 not working at all during the previous year.

ii) Labor force nonparticipation rate-

Fraction of civilian, nonstudent males aged 18-64 not in the labor force at all during the previous year.

iii) Annual unemployment rate-

Fraction of male labor force participants who were unemployed for at least one week in the year.

iv) Part-time/total employment-

Fraction of males working at least one week in the year who usually worked part-time (less than thirty-five hours per week).

v) Mean hours per week of full-time workers-

Mean hours worked per week of males who usually worked full-time during the year (at least thirty-five hours per week).

vi) Median/mean wage-

Median/mean hourly wage of males who worked during at least one week in the year and had positive wage \& salary earnings and no self-employment earnings (\$1993). The wage rate is calculated by dividing annual earnings by annual hours. The latter is calculated as: (hours usually worked per week) multiplied by (weeks worked in the year). See endnote 23 for a description of how we handled topcoding. 


\section{Notes}

${ }^{1}$ The employment-population ratio is total civilian employment divided by the civilian noninstitutionalized population over 16 years of age.

2"Whites" refers to white non-Hispanics. "Nonwhites" are all others.

${ }^{3}$ The conventional employment rate follows the same general pattern over this period, but with movements in the opposite direction (Council of Economic Advisors, 1994, Table B-37).

${ }^{4}$ The standardized rates are given by:

$$
\frac{1}{n} \sum_{i j k} n_{i j k} R_{i j k}
$$

where $i$ is age group $(18-24,25-39,40-54,55-64$ years), $j$ is race (white, nonwhite), and $k$ is years of schooling $(<12,12,13-15,16+) . n_{i j k}$ is the number of individuals in the $i j k$ cell in 1967 , and $n$ is the size of the 1967 population. $R_{i j k}$ is the activity rate (e.g., jobless rate) in the $i j k$ cell in a given year.

${ }^{5}$ The choice of 1967 as the base year, although having intuitive appeal, is, to an extent, arbitrary. We have experimented with using the mean population structure from 1967-1992 as an alternative base. The overall patterns remain very similar. Two slight exceptions are that the upward trends in standardized nonwork and nonparticipation are a little more pronounced using the 1967 base.

${ }^{6}$ It is possible that standardizing on more variables would alter the impact of demographic change.

${ }^{7}$ Application of the Das Gupta (1978) decomposition requires using the mean of the two populations (1967 and 1992) as the base. The rate effect in the table differs from that given by comparing the 1992 standardized value with the 1967 actual value in Figure 1 because of the difference in the base populations used. The rate effects shown in Table 3 are given by: 


$$
\sum_{i j k}\left(\frac{\frac{n_{i j k}}{n}+\frac{N_{i j k}}{N}}{2}\right)\left(R_{i j k}-r_{i j k}\right)
$$

where lower cases refer to 1967 values and upper cases to 1992 values.

The total demographic effect is given by:

$$
\sum_{i j k}\left(\frac{r_{i j k}+R_{i j k}}{2}\right)\left(\frac{N_{i j k}}{N}-\frac{n_{i j k}}{n}\right) .
$$

${ }^{8}$ For high school graduates with $1-40$ years of experience the approximate age range is $18-58$ years.

${ }^{9}$ Our results show that the absolute increase in joblessness has been greater for nonwhites, but that the relative increase has been greater for whites. Any apparent difference from Juhn (1992) in the racial difference in the trends is probably attributable to her focus on blacks and ours on all nonwhites.

${ }^{10}$ Further arguments against a labor supply-side explanation for the decline in male employment over the past twenty years include the fact that the percentage of the nonemployed receiving transfers has declined (Juhn, 1992). There is little support for the argument that the increased employment of women has reduced the work effort of their spouses, since within households with a nonemployed male the proportion of females in employment has not increased (Juhn, op. cit.).

${ }^{11}$ The BLS calculates the labor force participation ratio, defined as the fraction of the population in work or seeking employment in a typical week of the year. We refer to the reciprocal of this measure.

\footnotetext{
${ }^{12}$ See Hurd (1990) and references therein.
} 
${ }^{13} \mathrm{~A}$ person is classified as a discouraged worker if he is not participating in the labor force-not working or looking for work-because he believes he would not be able to find a job even though he looked for one.

${ }^{14}$ In the March CPS, individuals are asked how many weeks they were unemployed or on layoff in the previous year. There may be recall problems, especially for unemployment spells that were short in duration.

${ }^{15}$ This pattern closely resembles that for the more conventional unemployment rate (see Blank, 1994, Figure 1).

${ }^{16}$ Data are from the CPS. "Part-time" is defined as working fewer than thirty-five hours per week.

${ }^{17}$ There has been an increase in the proportion of part-time workers who would prefer full-time employment. That is, involuntary part-time work has increased. Blank (1990) reports that almost onehalf of male part-time workers took part-time jobs because full-time jobs were not available.

${ }^{18}$ When students are included, the white and nonwhite rates are 10.7 and 13.7 percent, respectively.

${ }^{19}$ The part-time employment rate for whites with only a high school diploma tripled over the period, from about 2 to 6 percent. That for nonwhites with only a high school diploma also increased substantially, from about 4 to 9 percent.

${ }^{20} \mathrm{We}$ are only able to show these trends from 1975 onwards, since data on hours usually worked per week were not collected in the CPS before 1975.

${ }^{21}$ Wage and salary workers are defined as individuals with positive wage and salary earnings and no self-employment earnings.

${ }^{22}$ Calculations which include self-employed workers as well as wage and salary workers show a similar trend. The median wage decreased from about $\$ 13.60$ to $\$ 12.40$. This series also shows greater cyclical sensitivity, because of the inclusion of self-employed workers. 
${ }^{23} \mathrm{We}$ emphasize the median wage rather than the mean wage because the mean wage is more sensitive to CPS topcoding. We have handled changes in the real value of CPS topcoding by (1) topcoding all earnings values at $\$ 99,999$ in 1993 dollars, (2) multiplying earnings at the topcode by 1.33 (following Juhn, 1992), and (3) because the real value of the CPS topcode was less than $\$ 99,999$ in 1980 and 1981, raising the earnings of all people with earnings at the CPS topcode in 1980 and 1981 to $\$ 99,999$ before multiplying by 1.33 .

${ }^{24}$ This view is consistent with Summers' (1986) explanation for the secular increase in unemployment; that is, within a demand-segmented labor market, there has been a decline in jobs in the high-wage sector. 


\section{References}

Berman, Eli and Stephen Machin. 1994. "Skill Biased Technological Change and Employment: Evidence from around the World." Mimeo, University College, London.

Blackburn, McKinley L., David E. Bloom, and Richard B. Freeman. 1990. "The Declining Position of Less Skilled American Men." In A Future of Lousy Jobs? Gary Burtless (ed.), Brookings Institution, Washington, D.C.

Blank, Rebecca M. 1990. "Are Part-Time Jobs Bad Jobs?" In A Future of Lousy Jobs? Gary Burtless (ed.), Brookings Institution, Washington, D.C.

Blank, Rebecca M. 1994. "Outlook for the U.S. Labor Market and Prospects for Low Wage Entry Jobs." Mimeo, Northwestern University.

Bound, John. 1989. "The Health and Earnings of Rejected Disability Applicants." $\underline{\text { American }}$ Economic Review, 79: 482-503.

Bound, John and George Johnson. 1992. "Changes in the Structure of Wages in the 1980s: An Evaluation of Alternative Explanations." American Economic Review, 82: 371-392.

Buron, Lawrence, Robert Haveman, and Owen O'Donnell. 1994. "The Utilization of U.S. Male Labor, 1975-1992: Estimates of Forgone Work Hours." Mimeo, University of Wisconsin-Madison.

Burtless, Gary. 1990. "Earnings Inequality over the Business and Demographic Cycles." In A Future of Lousy Jobs? Gary Burtless (ed.), Brookings Institution, Washington, D.C.

Clark, Kim and Lawrence Summers. 1979. "Labor Market Dynamics and Unemployment: A Reconsideration." Brookings Papers on Economic Activity, 13-60.

Clark, Kim and Lawrence Summers. 1982. "Labor Force Participation: Timing and Persistence." Review of Economic Studies, 49: 825-844.

Coleman, Mary, T. and John Pencavel. 1993. "Changes in Work Hours of Male Employees, 1940-1987." Industrial and Labor Relations Review, 46: 262-283. 
Council of Economic Advisors. 1994. Economic Report of the President. U.S. Government Printing Office, Washington, D.C.

Das Gupta, Prithwis. 1978. "A General Method of Decomposing a Difference between Two Rates into Several Components." Demography, 15: 99-112.

Haveman, Robert and Barbara Wolfe. 1984. "Disability Transfers and Early Retirement: A Causal Relationship?" Journal of Public Economics, 24: 47-66.

Howell, David R. 1993. "Technological Change and the Demand for Skills in the 1980s: Does Skill Mismatch Explain the Growth of Low Earnings?" Jerome Levy Economics Institute Working Paper No. 101

Hurd, Michael D. 1990. "Research on the Elderly: Economic Status, Retirement, and Consumption and Saving." Journal of Economic Literature, 28: 565-637.

Juhn, Chinhui. 1992. "Decline of Male Labor Force Participation: The Role of Declining Labor Market Opportunities." Quarterly Journal of Economics, 107: 79-121.

Juhn, Chinhui, Kevin M. Murphy, and Robert H. Topel. 1991. "Why Has the Natural Rate of Unemployment Increased over Time?" Brookings Papers on Economic Activity, 2: 75-126

Karoly, Lynn A. 1992. "Changes in the Distribution of Individual Earnings in the United States: 1967-86." Review of Economics and Statistics, 74: 107-115.

Levy, Frank and Richard J. Murnane. 1992. "U.S. Earnings Levels and Inequality: A Review of Recent Trends and Proposed Explanations." Journal of Economic Literature, 30: 1333-1381. Moffitt, Robert A. 1990. "The Distribution of Earnings and the Welfare State." In A Future of Lousy

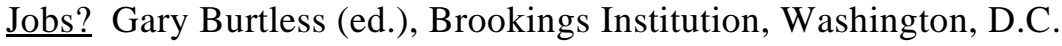

Murphy, Kevin M. and Robert H. Topel. 1987. "The Evolution of Unemployment in the United States: 1968-1985." NBER Macroeconomics Annual (1987), 11-58. 
Murphy, Kevin M. and Finis Welch. 1992. "Inequality and Relative Wages." American Economic Review, 83: 104-109.

Nasar, Sylvia. 1994. "More Men in Prime of Life Spend Less Time Working." The New York Times, December 1, 1994.

Parsons, Donald. 1980. "The Decline in Male Labor Force Participation." Journal of Political Economy, 88: 117-134.

Schor, Juliet B. 1991. The Overworked American, the Unexpected Decline of Leisure. Basic Books, New York.

Summers, Lawrence. 1986. "Why Is the Unemployment Rate So Very High Near Full Employment?" Brookings Papers on Economic Activity, 2: 339-383.

U.S. Department of Commerce. 1993. Survey of Current Business, vol. 74, no. 4. U.S. Government Printing Office, Washington, D.C. 